Article

\title{
The Relationship between the Spatial Configuration and the Fourth Sustainable Dimension Creativity in University Campuses: The Case Study of Zernike Campus, Groningen, The Netherlands
}

\author{
Isabelle Soares ${ }^{1, *}$, Claudia Yamu ${ }^{1}\left(\mathbb{D}\right.$ and Gerd Weitkamp ${ }^{2}$ (i) \\ 1 Department of Spatial Planning and Environment, Faculty of Spatial Sciences, University of Groningen, \\ 9747AD Groningen, The Netherlands; claudia.yamu@rug.nl \\ 2 Department of Cultural Geography, Faculty of Spatial Sciences, University of Groningen, \\ 9747AD Groningen, The Netherlands; s.g.weitkamp@rug.nl \\ * Correspondence: i.c.soares@rug.nl
}

Received: 27 September 2020; Accepted: 4 November 2020; Published: 7 November 2020

\begin{abstract}
To date, little is known about the spatial aspects of the creativity of university campuses and their public spaces. This study recognises that creativity is the fourth sustainability, because the spatial configuration of campuses and city-university accessibilities are 'creative solutions' conceived for human needs. At the same time, creative ideas depend on interactions between individuals and the built environment. Therefore, based on the theoretical framework of the scholars who have explored the spatial aspects of creativity, this study empirically investigates Zernike Campus, Groningen, and its public spaces using a mixed-methods approach that involves (1) a space syntax analysis of the campus's spatial configuration, (2) volunteered geographic information (VGI) of the users' perceptions, and (3) non-participatory observations of the interactions between people and the built environment in public spaces with high and low 'potential for creativity'. The results show that creativity cannot be explained simply by analysing spatial configurations, but that it also depends on the combination of the land-use mix, physical features, positive experiences, and perceptions of a sense of place which enable trust and interactions, and which facilitate creative encounters. Therefore, the mixed-methods approach applied here can help urban planners and designers to address public spaces more effectively, integrating conditions that support creativity.
\end{abstract}

Keywords: sustainability; creativity; space syntax; volunteered geographic information (VGI); public participatory GIS (PPGIS); university campus; science park; public space; urban design; landscape design

\section{Introduction}

The role of university campuses and science parks has essentially remained the same over time: they are spatial clusters that are conceived as environments to foster contacts and informal networks based on frequent face-to-face interactions [1,2]. The implementation of knowledge-based activities in one location is expected to provide synergy, creativity and innovation from previously unrelated disciplines [3]. Previous research found that the spatial configuration and physical features of university campuses play a fundamental role in people's interactions and learning activities, and hence their creativity [4-9].

Creativity emerges and develops in dynamic interactions between individuals as 'creators' and their environment [5]. Creativity is not an innate attribute of a single individual, no matter how intelligent and talented that person might be; it is influenced by local contexts, knowledge environments, 
spatial relations and spaces of interaction $[5,10]$. From a spatial perspective, Hillier explains that, in order to enable creativity, a (public) space must enhance contacts of the 'right kind'. He defines such contacts as "those more likely to make links between ideas and generate new ones" [11] (p. 82). Hillier [11] argues, in his space syntax theories, that creativity is the fourth sustainability, together with the other three: environmental, social, and economic sustainabilities. Creativity is therefore facilitated by the spatial configuration of cities. According to Peter Meusburger [5,10], creativity and new knowledge can be enabled by "meeting the right people in the right place at the right time" [5] (p. 137), and for creativity to occur, it further requires certain environmental conditions connected to a sense of place. Creativity is influenced by the way in which people perceive a place through its physical features. In other words, the complementary approach of both scholars leads to the assumption that creativity is a spatial and non-spatial phenomenon at one and the same time.

Empirical research in campus planning and design that deals with the interrelations between creativity and the built environment have been carried out from the city-wide scale to the building scale. From the citywide perspective, studies have investigated the spatial relationship and accessibility between cities and university campuses [12-14]. The masterplan design of campuses has been approached as entailing functional and visual units [7,15], and for the building scale, the relationships between the physical features of office spaces and people's contact to share tacit knowledge have been investigated [16-18]. Based on Hilliers' and Meusburgers' theoretical framework and the aforementioned empirical researches, it was noticed that the spatial aspects of the creativity of campus' public spaces have not yet been explored.

Public spaces at university campuses are creative and knowledge hubs that enable interactions and knowledge-sharing between people, and social wellbeing through a sense of place and community [19-21]. They are catalysts that bring people, ideas and resources together before a creative process can occur [5,22]. In reality, however, campus public spaces are often neglected spaces between buildings and classrooms, which-in many cases-may inhibit the generation, evaluation and adoption of creative ideas $[5,8]$. This can be attributed to the fact that campus planning and masterplan design tend to ignore the impacts of the built environment on human beings from the perspective of the individual $[9,23]$. In other words, the interface between campus' spatial configurations and the user perceptions of possible creative encounters are somewhat overlooked. Such issues are the result of the fragmented governance, interests and investments of the multiple campus stakeholders [24,25], which have implications for the quality of public spaces. These issues are recognised in the case study for this research: Zernike Campus Groningen, in The Netherlands.

We sought to close the research gap and address the research problem by answering the following questions: (1) How can the spatial configuration of the campus masterplan potentially enable movement and co-presence, and hence creativity? (2) Based on the interface between the spatial configuration and user perceptions, which campus public spaces provide high or low potential for creativity through spontaneous encounters, socialization, and meeting people from outside the campus? (3) To what extent do the physical features of public spaces affect high and low 'potential for creativity'? Do such features play a role in enabling or inhibiting creative encounters?

In order to answer these research questions, we applied a mixed-methods approach for the collection and analysis of the empirical data. The combination of methods consisted of (1) a space syntax analysis of the campus masterplan, in order to understand which public spaces have a high or low potential for pedestrian movement and co-presence according to the spatial configuration of the campus, and (2) the interface between the space syntax analysis and the quantification of the primary data that represents user perceptions, collected using volunteered geographic information (VGI). This allowed us to analyse public spaces with high and low 'potential for creativity' using the results of the categorisation and scatterplot analyses. Furthermore, (3) a non-participatory observation was conducted in order to show the role played by the physical features of public spaces in interactions between people and the built environment. 
An improved understanding of the spatial aspects of creativity can help urban planners and designers to address the design of public spaces more effectively, integrating conditions that support creative encounters. This research adds to the arenas of social and spatial sustainability, sustainable campus planning and design, learning environments, place-making, and geographical information science (GIScience). The remainder of the paper is structured as follows. The literature review in Section 2 addresses space syntax theory and empirical studies of university campus planning and design, the importance of human perceptions in the investigation of creativity and creative encounters, how cities and campuses are shaped by creativity, and how the public spaces that enable that creativity are fundamental to the sustainability of a campus environment. Section 3 describes the data collection and methodology, and this is followed by a discussion of the main results. The Section 4 contains the conclusion, limitations and recommendations for future work.

\section{Literature Review}

\subsection{Spatial Configuration: Space Syntax for University Campus Planning and Design}

Pioneered by Hillier and Hanson [26], space syntax is a theory and a method for the analysis of the spatial configuration of cities. Space syntax suggests that the configuration of the urban grid itself is the main generator of a city or neighbourhood's pattern of movement [27]. It entails the analysis of mathematical street network models that calculate configurative spatial relationships, applying a graph-theoretical approach, and thus indicating the dynamics of urban systems [28-30]. While the method can be used to understand the spatial configuration of the built environment, the results must be linked to an understanding of societal processes and human behaviour [28,31]. Space syntax analyses work with the concept of sightlines indicating movement paths, termed 'axial lines', to abstract reality. Such axial lines, in their minimal set for a whole urban entity, are represented as an 'axial map'.

Based on a study of campus planning and design using space syntax, Penn et al. [18] explain that the spatial configuration of a campus influences random contacts between people, which are fundamental to the facilitation of new ideas and tacit knowledge, and hence creativity. For university campus planning and design, space syntax was empirically tested in various cities and across different scales. The studies explored the ways in which the spatial configuration, patterns of space use, movement, and subjective perceptions affect the interactions between students and academics [32]; the ways in which the spatial aspects of the public realm affect the perceived qualities of publicness [33]; the relationship between campus life and public spaces [34]; the socio-spatial aspects of informal interactions and learning [35]; campus spaces that evoke positive feelings and enhance place-making [36]; the degrees and forms of publicness and their relationship to the spatial configuration of a university campus [37]; and masterplan typologies and city-campus spatial accessibilities [13,38].

Various empirical studies have shown the advantages of space syntax analyses; for example, by demonstrating the importance of campus' spatial configuration for enhancing social life and encounters. The method is a descriptive way of envisioning how a network of pathways works to facilitate or inhibit the potential of movement patterns, co-presence and social capital [39-41]. By means of such pathway analysis or graph representations, the spatial configuration of cities and neighbourhoods can be quantitatively analysed in order to determine the relative role that each space plays in the configuration of a system, as a whole or in its parts [31,42]. The method is a fine tool to test and review the adequacy of planning and design solutions, and to immediately verify their validity. In other words, it is a tool for designing, shaping, maintaining and changing creative clusters, such as university campuses [43]. However, other studies have pointed out certain limitations of the method; these relate to the 'simplified' way in which space syntax represents the built environment [44-46]. The method integrates (or reduces) the spatial configuration, physical features, human behaviours, and the experiences of cities and neighbourhoods to a single description: axial lines.

Netto [45] argues that there are three significant forms of reductionism embodied in the space syntax approach: (1) the reduction of spatial practices to movement, (2) the reduction of social 
interaction to bodily presence in public spaces, and (3) the reduction of urban space to its syntactic properties. Seamon [44] adds that space syntax simplifies the role of places and the sense of place into measurable dimensions, analytically representing the network of public spaces-such as roads, paths, rooms or corridors-as linkages of connections and interactions [44]. Additionally, Pafka et al. [46] provide a review of the literature, which suggests that several empirical space syntax studies that addressed walkability and public spaces have presented problematic results. This is because the representation of the spatial network by axial lines ignores the micro-morphology of spaces, neglecting elements such as sidewalks, vegetation, street furniture and traffic. These limitations suggest a need to combine complementary methods with space syntax in order to fully understand the interface between the built environment and people's perceptions and experiences, and how this interface plays a role in creative encounters in campus public spaces.

\subsection{Mapping People's Perceptions and Observing Interactions}

Through perceptions, people interpret unconnected stimuli to construct something meaningful about a certain environment [47]. Heft [48] explains that perceiving and acting are fundamental to almost all complex organisms for sustaining life. Both processes operate synergistically. Perceptions and objective properties of places can be mapped and quantified using PPGIS [49,50] methods, which identify relationships between environmental factors, local experiences and everyday behaviour [51,52]. PPGISs have been used in various place-based studies, such as a combination of accessibility analysis with PPGIS of users' environmental perceptions [53], to map locations that enhance relaxation and reduce stress among university students [32], the multiple-level influences of health behaviours and factors that influence active travel by older adults [54] and the application of PPGIS for planning urban green infrastructure [55]. With PPGIS, more specifically VGI, the researcher can collect perceptual data while citizens act as active sensors within an environment [49].

From a conceptual and research perspective, VGI intersects with the more established field of PPGIS in the development of Internet-based tools to create, assemble and disseminate geographic information provided voluntarily by individuals [49,56]. The integration of Internet-based GIS and citizen information can reveal the strength of intersecting networks in community management, facilitate communication between different groups of stakeholders and empower citizens to participate effectively in the processes of urban planning and design and policy-making [57,58].

Marcus et al. [59] explain that the built environment engages humans not only through its locations for different physical activities and uses but also mentally, by providing opportunities for learning and meaning creation. Therefore, investigating real-life situations with VGI perceptual data and observing interactions between people and the built environment are effective ways to understand human behaviour and needs $[60,61]$. Observations provide insights into how people, objects, artefacts and other features of the built environment interact [62]. With observation, it is possible to collect and analyse information about physical aspects that influence the frequency of VGI-mapped perceptions. It is a useful resource to subject practical actions and activities in situ to detailed analysis [63].

Observations of interactions between people and the environment have been empirically tested in various urban design and planning studies looking at 'flexible spaces' [64], 'life between buildings' [65,66], the sense of community in campus public spaces [8], 'urban design features' [67], 'landscape taxonomy' [68,69] and the 'post-occupancy evaluation (POE) of outdoor spaces' [70]. Such observational studies suggest that the urban design of creative clusters, such as university campuses, should promote combinations of urban forms, city blocks, building types and frontage types that suit combinations of land uses, activities and people [6].

\subsection{Creativity as the Fourth Sustainability through the Lens of Space Syntax and the Sense of Place}

In order to understand the spatial aspects of creativity, it is necessary to recall the definition of creativity. Boden [71] defines it as "the ability to come up with ideas or artefacts that are new, surprising and valuable" [71] (p. 1). As all people are creative, and constantly need and apply creativity 
to solve their everyday problems, creativity is a characteristic that does not belong solely to the art disciplines [72,73]. It is, therefore, not the same as innovation. Creativity relates to the generation of new and valuable ideas, whereas innovation is about the implementation of those ideas [5]. For this study, we use the concept of Shalley et al. [74], who suggest that "creativity involves the production, conceptualization, or development of novel, original and useful ideas, processes, or procedures by an individual or by a group" [74] (p. 215).

This study approaches the spatial aspects of creativity from two complementary perspectives. The first relates to Hillier's [11] hypothesis that creativity is the fourth sustainability. He proposes that the other three sustainabilities (economic, environmental, and social) are consequences of the spatial form of a city, whereas the fourth, creativity, is the reason for it. Hillier [11] uses space syntax theories to explain the way in which city networks are enabled by multiple human necessities, which he conceptualises as 'creativity'. He explains that the development of a city is a continuous process of co-evolution between human needs and urban form, establishing a direct rapport between the two [11]. Because of creativity, interactions are established and solutions regarding spatial relations are solved, for example, by creating railways and transport lines and hence accessibility between regions and neighbourhoods. Therefore, university campuses and city-university spatial relations are regarded here as 'creative solutions' or 'spatial solutions' conceived for human needs. The fundamental idea of the organisation of academic and research-based institutions into spatial clusters was a 'creative solution' to enable the co-presence of educated individuals in the same area, and hence enable long-term economic growth $[75,76]$.

As mentioned above, space syntax analyses describe cities as a series of linkages and measurable entities that demonstrate stronger and weaker connections and relationships [40]. Therefore, a complementary theoretical framework that addresses people's perceptions of their sense of place and public spaces is necessary to understand creativity as the fourth sustainability. For that reason, the second perspective builds on Peter Meusburger's $[5,8,77]$ studies, which propose that the success of a university campus or any other type of creative cluster derives from the interface between the built environment and causal interactions between people that facilitate the generation, diffusion and application of creativity. This is connected to theories of a 'sense of place'. A sense of place is defined here as the interactions of individuals' bodily routines rooted in a geographical locale that often becomes a place of interpersonal and communal exchange, meaning and attachment [40]. A sense of place thus enables trust, and hence the exchange of information between people interacting in an environment [78]. In line with Meusburger, Raymond et al. [79] explain that a sense of place is a property of the relationship between perception-action and social construction processes within place-based experiences. People are emotionally attached to places, prefer certain places, or gather regularly at specific places for various functional, symbolic and emotional reasons [5].

This literature review leads us to suggest that 'creative solutions' both shape university campuses and their public spaces, and are shaped by these places. The conceptual model (Figure 1) illustrates that: (1) cities are creative inventions, and therefore the spatial accessibilities of campuses and city campuses have certain spatial configurations because of creativity; and (2) the public spaces of university campuses are fundamental to enabling contacts of the 'right kind' through spontaneous encounters, socialisation and meeting people from outside the university. 


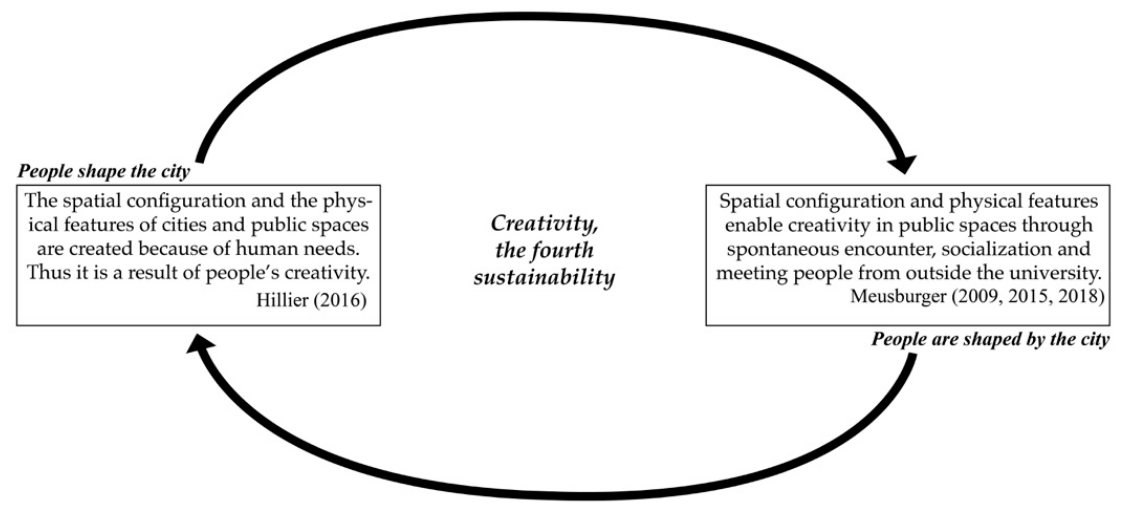

Figure 1. Understanding the relationship between the city and creativity as the fourth sustainability.

\section{Materials and Methods}

\subsection{Case Study: Zernike Campus, Groningen, The Netherlands}

Groningen is a university city in the north of The Netherlands, with a population of 231,299 [80]. In total, there are currently around 60,000 students from various academic institutions [81], the largest of which is the University of Groningen (UG), founded in 1614, with over 30,000 students. The UG has two locations and two types of campus: the 'dependent urban fabric' and the 'autonomous urban fabric' [38,82]. At the 'dependent urban fabric', the university buildings and departments are scattered across the city centre, while Zernike Campus, the 'autonomous urban fabric', is a top-down modernistic masterplan, located on the edge of the city (Figure 2).

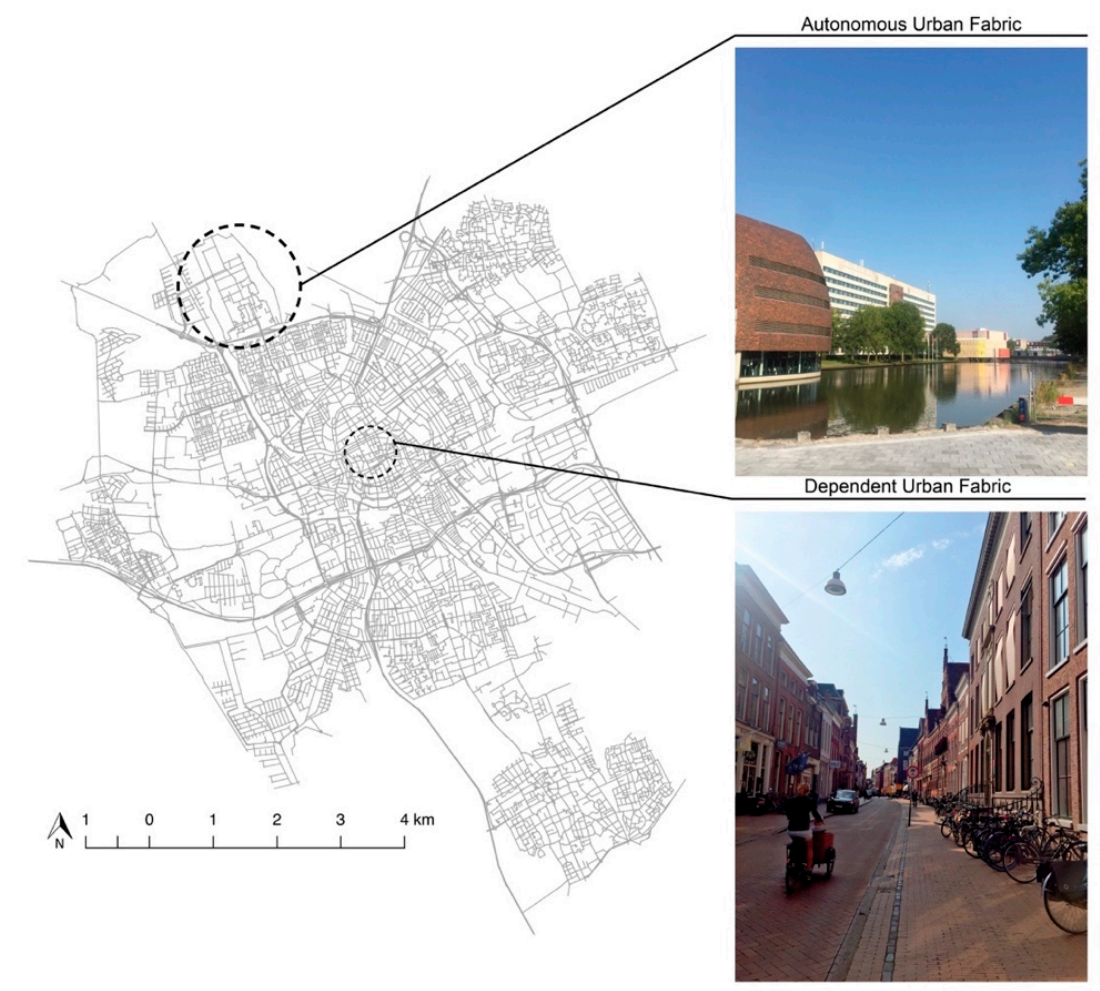

Figure 2. The city of Groningen with its two types of university campus.

Zernike Campus was established in the late 1960s as an independent and segregated cluster of buildings. Both the spatial segregation between the campus and the city and the top-down modernistic masterplan was a typical 'creative solution' in European cities around that time. The broad availability 
of land on the city periphery, influenced by easy car access, encouraged the establishment of the campus because of the need for separated (or even isolated) spaces for research and education in the natural sciences and technology $[83,84]$. In the context of The Netherlands, such campuses, also called 'satellite science precincts' [85], represent $28.5 \%$ out of 35 campuses [86]. We chose Zernike campus as the study case because it is representative of the Dutch context, and it provides the possibility for local expert knowledge and a convenient sample.

Figure 3 shows the land-use distribution, with a clear separation between academic activities (south) and knowledge-intensive and research-based companies (north). Diverse urban functions-such as a library, a sports centre, canteens, restaurants and cafés-are clustered in the southern part of the campus, around the academic buildings. The masterplan satellite science campuses are commonly composed of buildings that were designed and constructed at different times, implemented freely in open green fields, producing a drive-through, sprawling and isolated atmosphere [7]. In this context, the buildings and public spaces are spatially and socially disconnected from their immediate context $[7,82]$. This lack of continuity between the buildings and public spaces is classified by Hajrasouliha [15] as a 'weak spatial structure'.

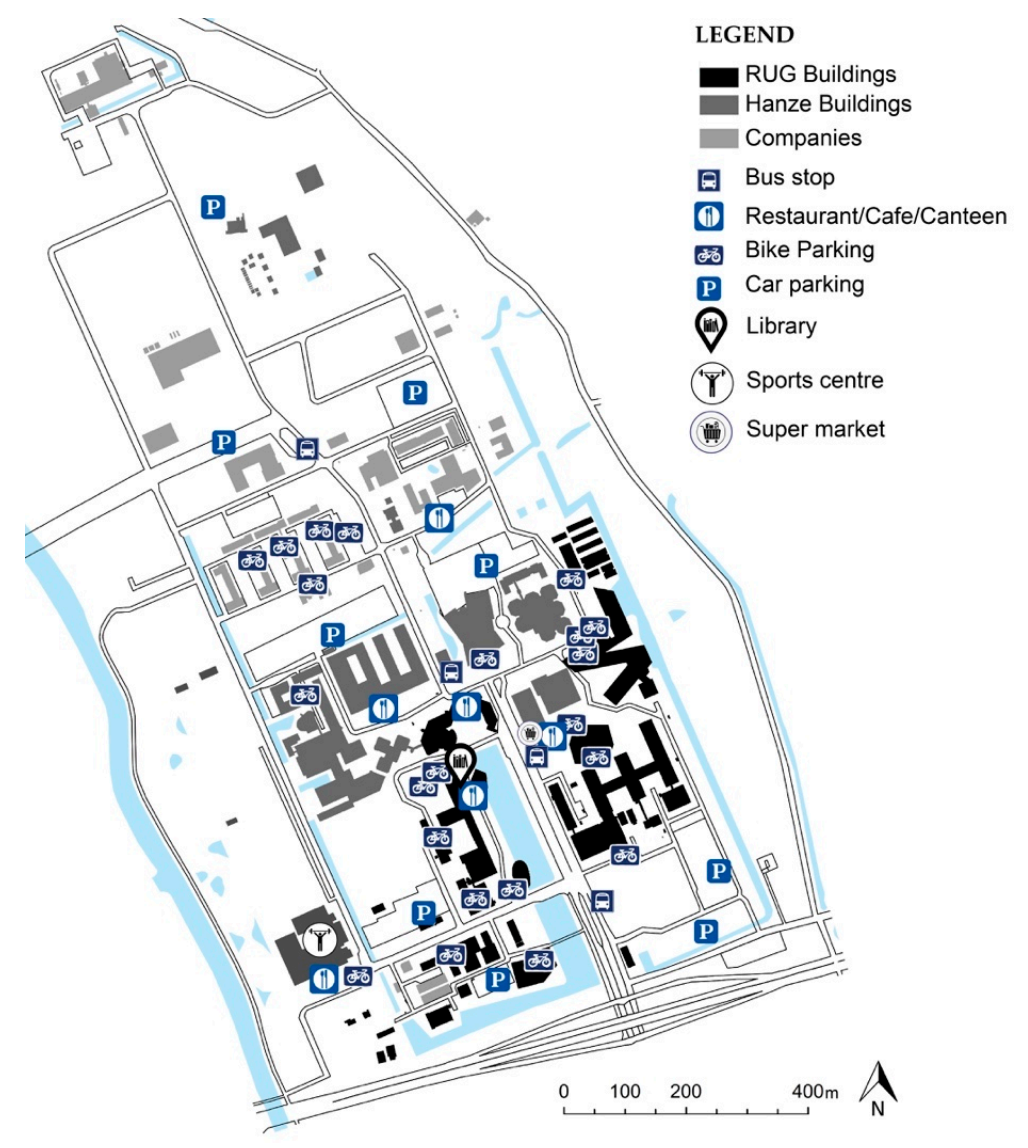

Figure 3. Zernike Campus land use.

\subsection{Computational Analysis with Space Syntax}

We applied space syntax to analyse the spatial configuration of the campus area in order to investigate its potential for movement, co-presence, and creative encounters. The axial lines were designed using Open Street Map (OSM) as a base map, applying the logic of an axial map. The pedestrian-centred axial map represents spaces with non-restricted access, such as streets, sidewalks, plazas, internal passages, and corridors on the ground floor of university buildings. The syntactical analysis was carried out using Depthmap software [87]. 
For the analyses, we applied the normalised angular choice measure (NACH) to calculate the 'potential through-movement' $[88,89]$ of the campus. Angular choice has the strongest and the most consistent correlation with pedestrian movement compared to any other syntactic measure, such as integration $[88,90,91]$, since humans tend to estimate the angular distance to reach destinations while walking through the environment [92-94]. In other words, NACH represents the likelihood of a street segment to be part of a particular path. Thus, high choice values channel high flow between an origin and a destination [95], affecting movement and social transactions, and consequently, the transmission of tacit knowledge. Two radii were used: the city-wide radius $\mathrm{N}$, depicting the logic of the whole campus, and the local radius $800 \mathrm{~m}$, representing a 10 minute walk.

\subsection{Volunteered Geographic Information (VGI)}

In order to understand the ways in which users perceive the 'potential for creativity' in campus public spaces, a map-based survey was carried out using the urban-focused web-based application Maptionnaire (maptionnaire.com, developed by Mapita, Helsinki, Finland) [96]. The data collection method was based on a study by Yaylali-Yildiz et al. [33]. Participants were asked to draw polygons on the campus map that represented their experiences and perceptions of indoor and outdoor campus public spaces. The map-based questions and their definitions are presented in Table 1.

Table 1. Map-based questionnaire questions and definitions.

\begin{tabular}{ll}
\hline \multicolumn{1}{c}{ Question } & \multicolumn{1}{c}{ Definition } \\
\hline $\begin{array}{l}\text { Indicate on the map the public space(s) that } \\
\text { provide(s) possibilities of spontaneous encounter }\end{array}$ & $\begin{array}{l}\text { Spontaneous encounters are unexpected findings of } \\
\text { valuable ideas, people and things influenced by the } \\
\text { built environment [5]. }\end{array}$ \\
\hline $\begin{array}{l}\text { Indicate on the map the public space(s) that } \\
\text { provide(s) possibilities of socialisation }\end{array}$ & $\begin{array}{l}\text { Tacit knowledge is shared, transferred and } \\
\text { accumulated through socialisation between creative } \\
\text { individuals [5,10,97] }\end{array}$ \\
$\begin{array}{l}\text { Indicate on the map the public space(s) that } \\
\text { provide(s) possibilities of meeting people from } \\
\text { outside the campus (MPFOC) }\end{array}$ & $\begin{array}{l}\text { Campuses should be activity hubs that serve not only } \\
\text { students and staff but the wider population of a town } \\
\text { and region [98]. }\end{array}$ \\
\hline
\end{tabular}

In total, we collected 224 polygon responses. The participants were university students and employees from various academic institutions. Before starting the survey, the participants were informed about the research subject and privacy regulations. The empirical data were collected in line with The Netherlands Code of Conduct for Research Integrity [99], the General Data Protection Regulation [100], and the Declaration of Helsinki, and the protocol was approved by the Ethics Committee of the Faculty of Spatial Sciences at the UG. The data were collected during weekdays in April 2018 across the southern part of the campus, where academic institutions are located and high pedestrian movement occurs. Since the northern part of the campus is currently under development, the user movements are predominantly cycling and vehicle-based.

The survey was conducted as an in-class experiment by Bachelor's students of the 'Methods for Academic Research' course unit at the UG. For reasons of consistency, the proper use of the Maptionnaire web tool, and the replicability of data collection, the students who collected the data received a short training session which presented the essential information. Thus, a controlled procedure was followed using the same questions for all of the participants.

\subsection{Combining the Space Syntax Model with Volunteered Geographic Information (VGI) Data}

To understand the interplay between the spatial configuration of the campus and people's mapped perceptions, we combined and categorised the space syntax results with the VGI perceptual data using geographical information systems (GIS). Two values were attributed to the segments map, representing the campus's spatial structure: (1) the NACH R800m values, representing the potential for 
pedestrian movement and co-presence; and (2) the average result of the VGI perceptual data, indicating the frequency of spontaneous encounters, socialization, and possibilities for meeting people from outside the campus (MPFOC). The attribution of VGI values to the segments was calculated using 'spatial join', in accordance with the average frequency of the polygon responses that intersected the segments. In other words, every street segment has a space syntax value (NACH) and a VGI value. This procedure enabled us to locate and visualise public spaces with a high or low 'potential for creativity'. The public spaces that we describe as having a high 'potential for creativity' are those shown to have high VGI values and concurrent high NACH R800m values.

The NACH R800m results, representing a 10-min walk, were combined with VGI, since the observations confirmed that people tend to walk up to $10 \mathrm{~min}$ between key destinations on campus, such as classrooms, offices, cafeterias, the library, the supermarket, and the Sports Centre. Furthermore, a scatterplot analysis was conducted in accordance with the following categorisation values: (1) high VGI and high NACH R800m, (2) high VGI and low NACH R800m, (3) low VGI and high NACH $\mathrm{R} 800 \mathrm{~m}$, and (4) low VGI and low NACH R800m. This method represents geo-referenced 'patches' of human interactions, rather than networks of communication between people. The categorisation and scatterplot analyses formed the basis for the non-participatory observation analysis.

\subsection{Observation of Interactions between People and the Built Environment}

Although the interface between the space syntax analysis and the VGI perceptual data shows the variation of the 'potential for creativity' throughout the campus public spaces, the additional qualitative method of the non-participatory observations sheds light on how the people, objects and other features of the physical environment interact [62,101-103]. In other words, the non-participatory observation yields information concerning the interface between the public spaces' physical features and peoples' behaviour, without actively interacting with the participants. This method was chosen because the observation, recording and analysis of peoples' activities and interactions, despite the limitations, provides access to social action, allowing aspects of particular events to be subjected to detailed repeated scrutiny $[62,104]$. With this method, only visible behaviour can be recorded, and intentions and motives cannot be unveiled. Observation is not claimed to be a complete or natural representation of the activities of groups and individuals, but rather a portion of their daily activities [63,105].

For the present research, we conducted structured observations and collected empirical data, such as photography and short videos, at nine locations across the campus. The observations and content analysis were based on the studies by Mehta [61,69], Kenney et al. [8], and Costa and Lopes [102]. Nine locations for observation were selected based on the above-mentioned categorisation and scatterplot analyses. For each location, we spent 10 minutes observing the interactions between people and the built environment during lunchtime (between 12 noon and 1 p.m.) on weekdays in the first two weeks of June 2019. The researcher was located at a discreet vantage point for maximum visibility of activity at each location, and they recorded activities in detail using photo and video cameras. The non-participatory analysis demonstrates that the results of the high and low 'potential for creativity', measured through the interface between the VGI perceptual data and space syntax, may or may not be reflected in the observed relationship between people and the built environment. This analysis thus describes the ways in which the physical features of public spaces-such as paved surfaces, lighting, shared spaces, sitting opportunities, trees, water features, shade and shelter, signs, cafés or dining halls $[4,61,64-68]$-play a role in enabling or inhibiting creative encounters.

\section{Results and Discussion}

\subsection{Potential for Creative Encounters through Spatial Configuration}

The results of the space syntax analysis are represented graphically on an axial map using a scale of colours ranging from red, referring to highly accessible streets, to blue, referring to segregated streets. Figures 4 and 5, and Table 2 show the results of the global and local NACH for the campus masterplan 
model. The analyses represent the potential through-movement for pedestrians within the campus (NACH RN) and 10-min walks (NACH R800m).

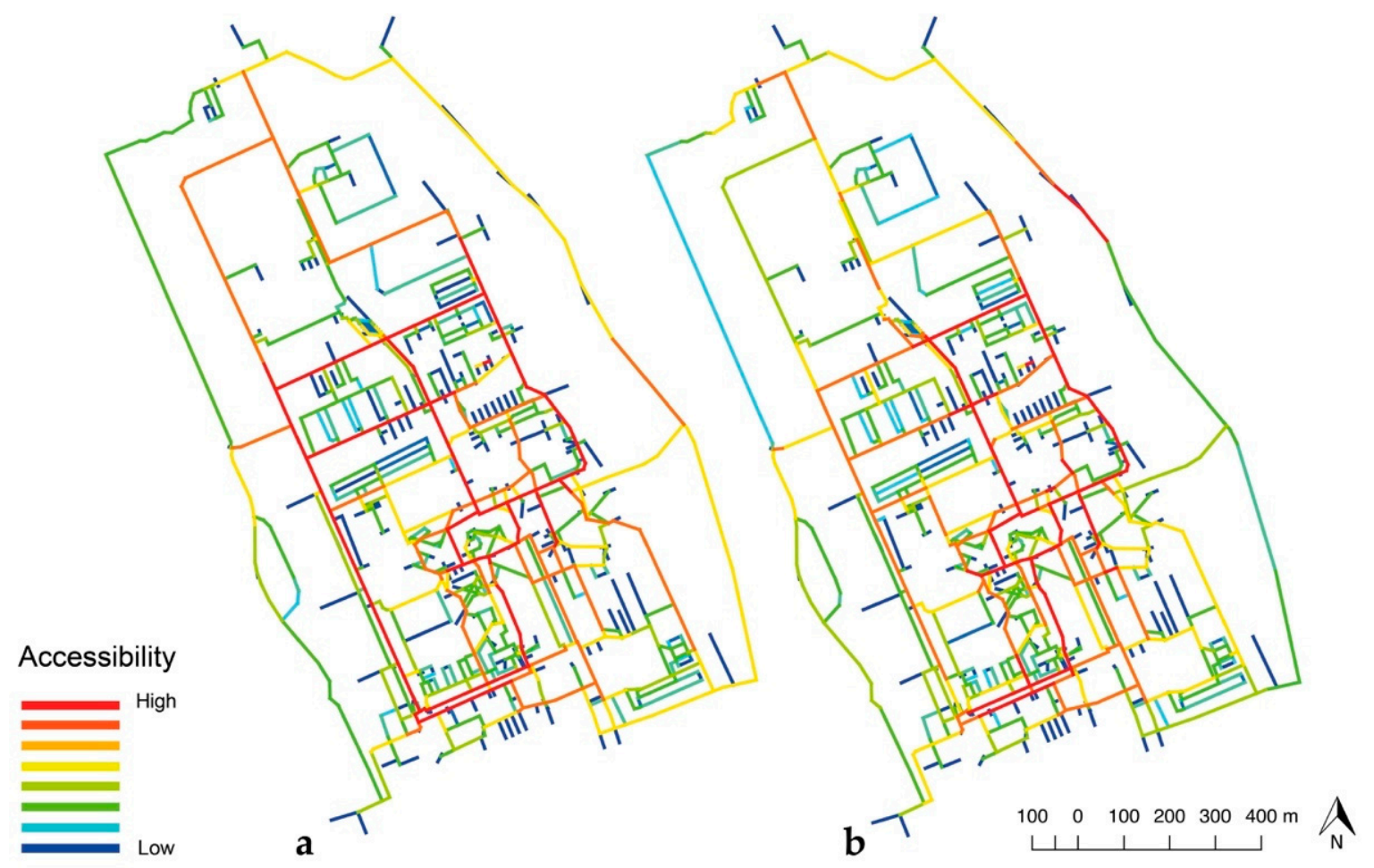

Figure 4. Normalised angular choice (NACH): (a) NACH Rn; (b) NACH R800m.

Table 2. NACH analysis for selected streets. For the location of the segments, see Figure 5.

\begin{tabular}{lcc}
\hline & NACHRn & NACH R800m \\
\hline System min. & 0.00 & 0.00 \\
System mean & 0.86 & 0.88 \\
System max. & 1.47 & 1.42 \\
01. De Mudden (street) & 1.37 & 1.31 \\
02. Kadijk (street) & 1.36 & 1.28 \\
03. Zernikelaan (street) (1) & 1.47 & 1.42 \\
04. Zernikeplein (street) & 1.29 & 1.30 \\
05. Kapteynborg building (corridor) & 0.82 & 0.84 \\
06. Blawborgje (street) & 1.41 & 1.23 \\
07. Landleven (street) & 1.35 & 1.39 \\
08. Duisenberg building (corridor) & 1.19 & 1.23 \\
09. Sports Centre (corridor) & 0.90 & 0.93 \\
10. Exam hall (corridor) & - & - \\
11. De Deimten (street) & 1.29 & 1.32 \\
12. Growelerie (street) & 1.29 & 1.29 \\
13. Supermarket & - & - \\
14. Zernikelaan (street) (2) & 1.30 & 1.28 \\
15. Nijenborgh (street) & 1.32 & 1.29 \\
16. Energy Academy building (corridor) & 1.09 & 1.08 \\
17. Nettelbosje (street) & 1.27 & 1.32 \\
18. Mercator building (corridor) & 0.65 & 0.72 \\
\hline
\end{tabular}




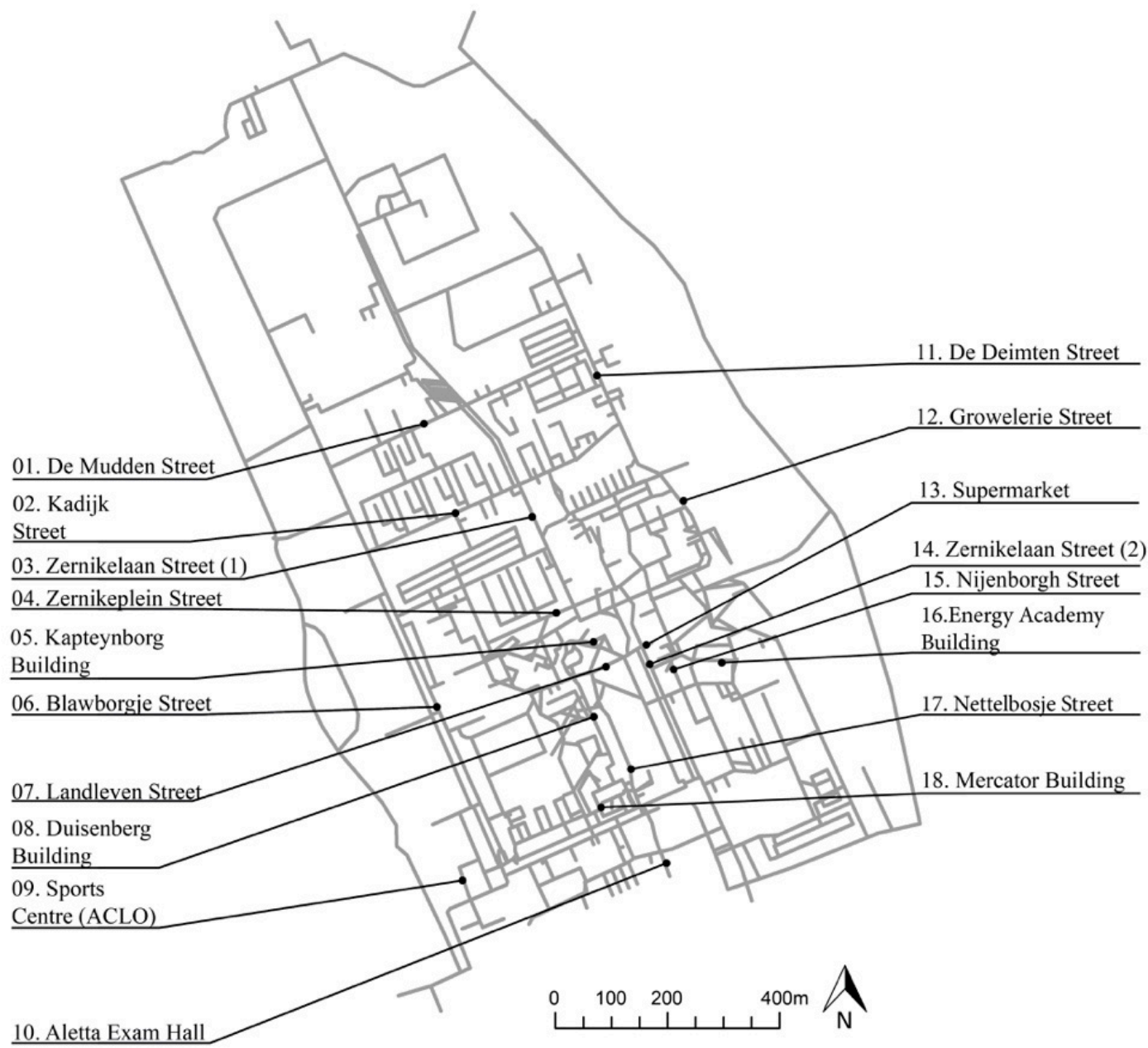

Figure 5. Spatial configuration of the campus masterplan including street names.

The results show that, although the axial map was designed with a focus on spaces dedicated to pedestrian movement, the results of the global measure (NACH RN) highlight the high values of movement for vehicular, cycling and pedestrian routes throughout the campus's maxi-grid of straight streets (Figure 4a). Such a grid was a creative solution adopted in the 1960s, mainly to allow car circulation. High NACH RN values were found for the 'spatial spine' of the campus, comprising the streets Zernikelaan, Kadijk, Blauwborgje and De Mudden (Figure 5). The local measure, NACH R800m (Figure 4b), resulted in high values on the Landleven, Nettelbosje, De Mudden, Kadijk and De Deimten Streets. This, therefore, highlights the urban spine with links to the maxi-grid. Legeby [37] suggests that a high potential for movement and co-presence is of major significance for the social relations and social capital that may potentially emerge in campus public spaces.

Interestingly, the results showed that the internal corridor of the Duisenberg building has high values for local $\mathrm{NACH}$ (R800m), which are comparable to certain outdoor segments. These high values can be explained by its central location and connectivity to adjacent roads and other indoor circulation (Table 2). These results demonstrate that public spaces (or segments) with strong choice-values occur when many of the shortest paths, connecting all of the spaces to all of the other spaces in a system, pass through it [91]. However, the corridors of the Kapteynborg and Mercator buildings show low values. Such low values for segments that are not located in privileged and central areas can be attributed to the line depth of 'specified' routes, because indoor areas are often less visible, less accessible, and have a lower potential for movement. Based on Hillier et al.'s [27] 'natural movement' theory, the aforementioned results suggest that the spatial configuration of the campus grid 
yields attraction inequalities and privilege for some public spaces over others without the consideration of land use attractors.

\subsection{Superimposing People's Perceptions on Space Syntax Results}

The results of the space syntax analysis provided valuable insights into where creativity can potentially occur according to the spatial structure of the campus masterplan. However, it is important to understand, through user perceptions, which campus public spaces have high or low opportunities for creative encounters. Therefore, the space syntax analysis (NACH R800m) was superimposed on the VGI perceptual data (Figure 6). The grey colour range represents the polygons drawn by the interviewees in Maptionnaire. The darker the colour, the greater the opportunity for spontaneous encounters, socialization, and MPFOC. The results show that the location of the urban functions-such as academic activities, cafés and restaurants-influence the choice of indoor or outdoor routes, as well as combined routes. For example, the users indicated a high potential for creativity through socialisation and spontaneous encounters around Landleven Street and the Duisenberg building, which are centrally located and have a mixed land use. For high opportunities for MPFOC, the users mainly indicated the Sports Centre as a favourite place. Therefore, if interactions between people are to generate new knowledge through creativity, it is likely to occur between people from the same institution (UG), clustered in the south of the campus.

Figure 7 presents the interface between the space syntax and VGI perceptual data, categorised by (1) high VGI and high NACHR800m (red), (2) high VGI and low NACHR800m (yellow), (3) low VGI and high NACHR800m (blue), and (4) low VGI and low NACHR800m (grey). Although the grey category includes a considerable number of the segments, this research only focuses on spaces with high VGI or space syntax values. The results show that the public spaces (or segments) with the highest 'potential for creativity' belong to the red category, and that spontaneous encounters and socialisation are clustered around Landleven Street and the indoor and outdoor public spaces of the Duisenberg building. The opportunities for MPFOC occur predominantly at the Sports Centre. These results confirm the research hypothesis, showing that a high potential for creativity occurs in public spaces that enable an interplay between the high potential for movement and co-presence and, at the same time, high opportunities for spontaneous encounter, socialisation and MPFOC (see Figure 3).

For the yellow category (high VGI and low NACH R800m), the results show a few segments, which will be further addressed in the observation analysis. The blue category (low VGI and high $\mathrm{NACH}$ R800m) depicts a great number of segments. The high NACH R800m values essentially highlight the long and straight lines on the campus, which is a typical 'creative solution' for modernistic masterplans. However, for this category, only a few respondents drew polygons that overlap with high NACH R800m values. This is consistent with previous studies, which suggested that reducing places and a sense of place to syntactic properties might overlook social interactions, bodily presence, and the micro-morphology of public spaces [44-46]. 
Q01 - Public space(s) that provide(s) possibilities of spontaneous encounter
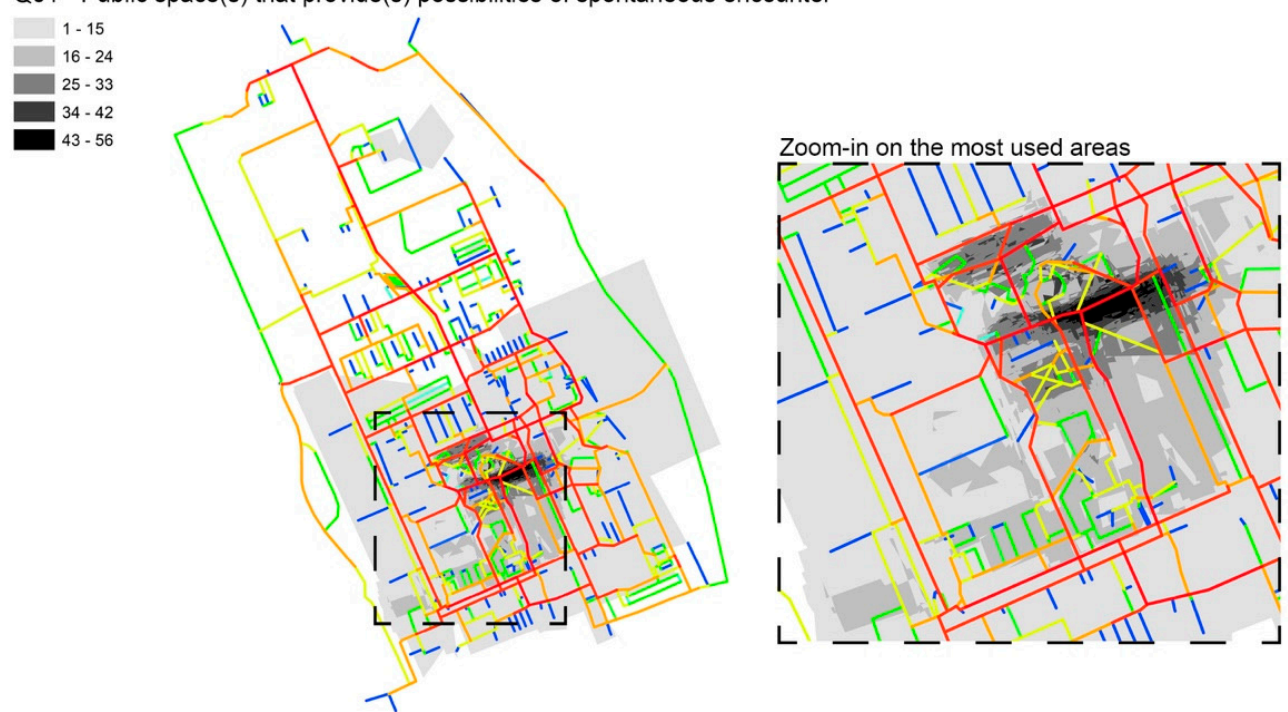

Q02 - Public space(s) that provide(s) possibilities of socialization
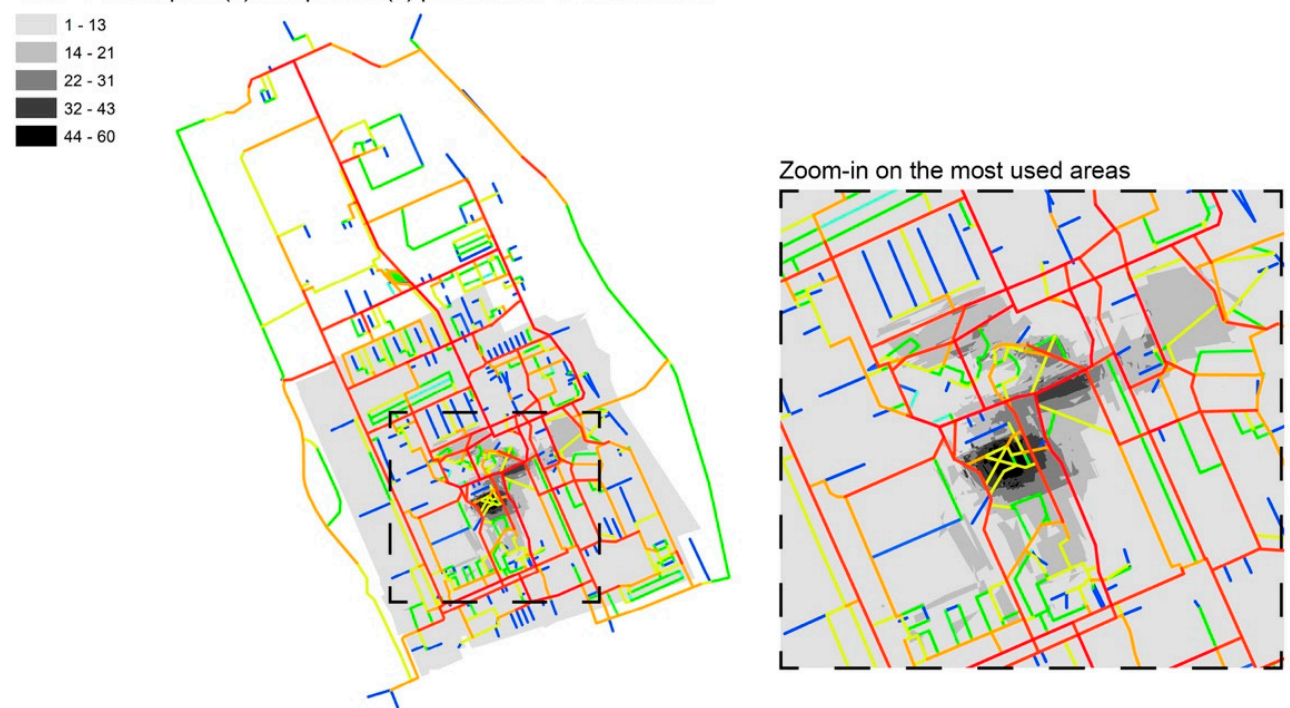

Q03 - Public space(s) that provide(s) possibilities of meeting people from outside the campus
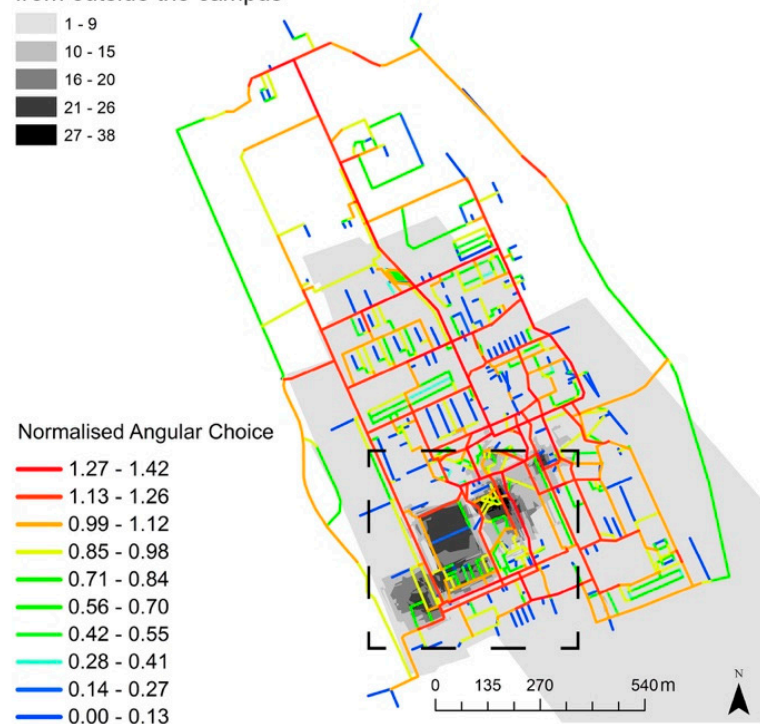

Zoom-in on the most used areas

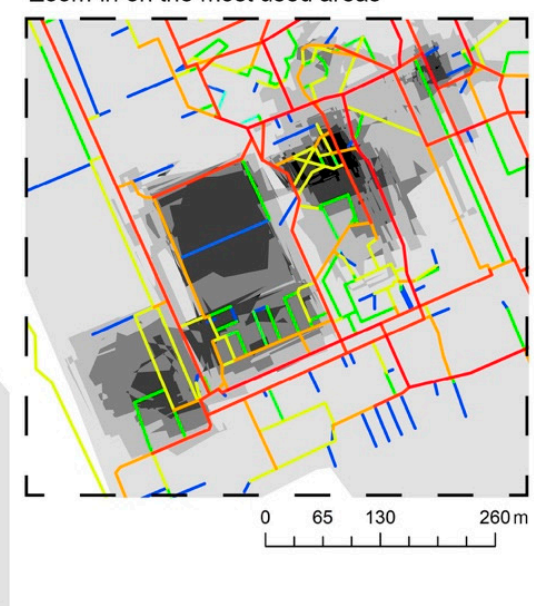

Figure 6. VGI perceptual data superimposed on NACH R800m. 


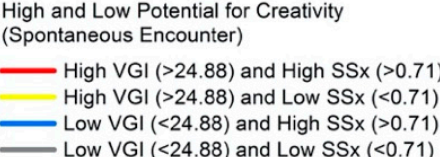

(Spontaneous Encounter)
High VGI $(>24.88)$ and High SSx $(>0.71)$
High VGI $(>24.88)$ and Low SSx $(<0.71)$
Low VGI $(<24.88)$ and High SSx $(>0.71)$
Low VGI $(<24.88)$ and Low SSx $(<0.71)$
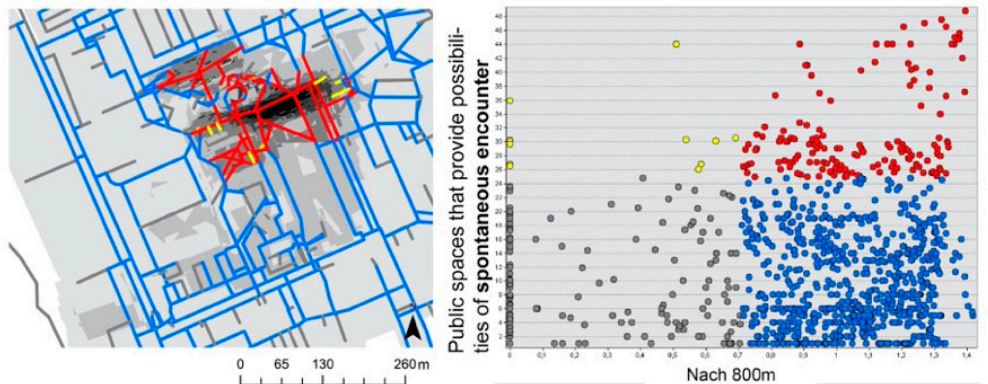

High and Low Potential for Creativity (Socialisation)
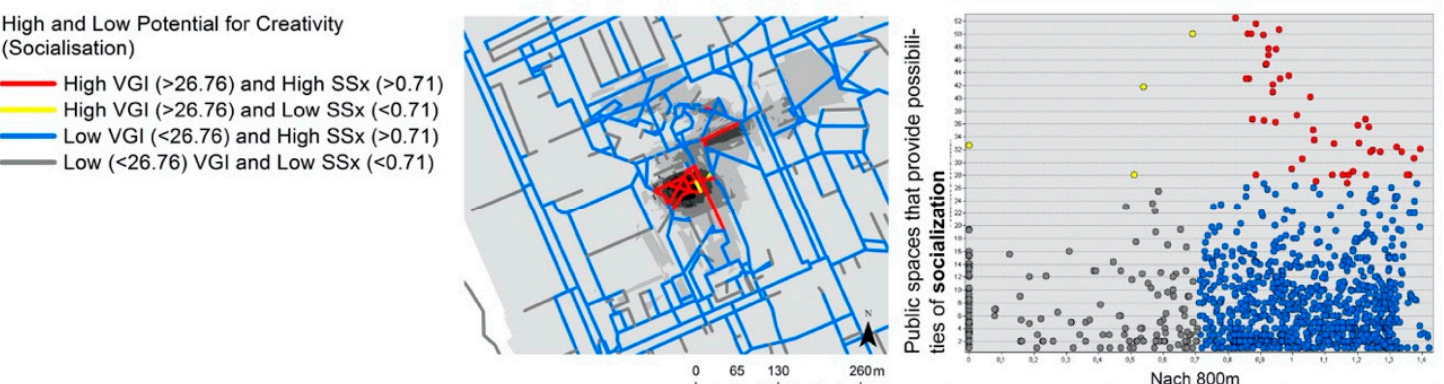

High and Low Potential for Creativity (Meeting people from outside the campus)

High VGI $(>17.58)$ and High SSx $(>0.71)$ High VGI $(>17.58)$ and Low SSx $(<0.71)$ Low VGI $(<17.58)$ and High SSx $(>0.71)$ Low VGI $(<17.58)$ and Low SSx $(<0.71)$
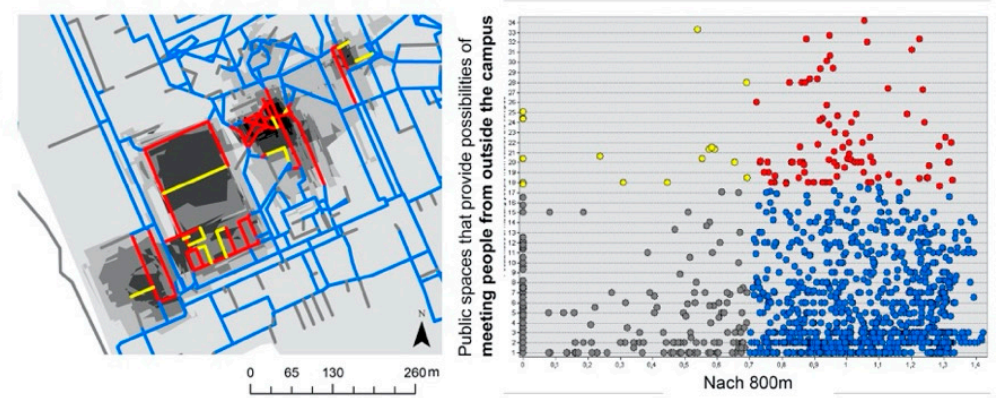

Figure 7. Axial lines and scatterplot analysis, representing the interface between the space syntax analysis and the VGI values for spontaneous encounters, socialization, and meeting people from outside the campus (MPFOC).

\subsection{Observation Analysis: Physical Features, Interactions and Creativity}

For the non-participatory observations, nine locations across the campus were selected for the analysis. This illustrates the extent to which the physical features of the built environment play a role in the high or low potential for creativity, and how their quality enables or inhibits creative encounters. Figure 8 shows photographs of the nine public spaces, which comprise three spaces in each colour category (red, yellow and blue).

The observations of public spaces in the red category illustrate why Landleven Street and the internal corridor in the Duisenberg building are the public spaces with the highest potential for creativity. They provide diversity, with amenities such as cafés, the library, the supermarket, water features, shared spaces, and seating opportunities. Such a concentration of amenities has established these spaces as 'community-gathering places' [61]. This shows the importance of clustering physical features, and the extent to which they can facilitate contacts of the 'right kind' [11] through 'common activities', such as buying a coffee, going to the canteen, or sitting on the same bench. The results for the yellow category (high VGI and low NACH R800m) imply that creative encounters in public spaces can be facilitated mainly by social activities and physical features, while the potential for movement and co-presence plays a minimal role. For example, the walkway between the football fields shows low potential for movement (0.53) but high opportunities for meeting people from outside the campus (20 respondents). It does not seem to matter that this space has low accessibility, because what attracts people is the sporting activity and the opportunity to encounter others. 
For the blue category (low VGI and high NACH R800m), the observation was conducted at the intersection of the Kadijk and Zernikelaan streets. This intersection is a typical vehicular and cycling-oriented environment, and forms a physical separation between the academic activities and companies located in the north of the campus. The observations show that this intersection is mainly used for goal-oriented pedestrian movement, when people walk to have lunch. As well as trees that provide shade, vehicular and cycling routes, and narrow sidewalks, the physical features of this public space do not encourage stationary activities, for example, and could inhibit creative encounters.

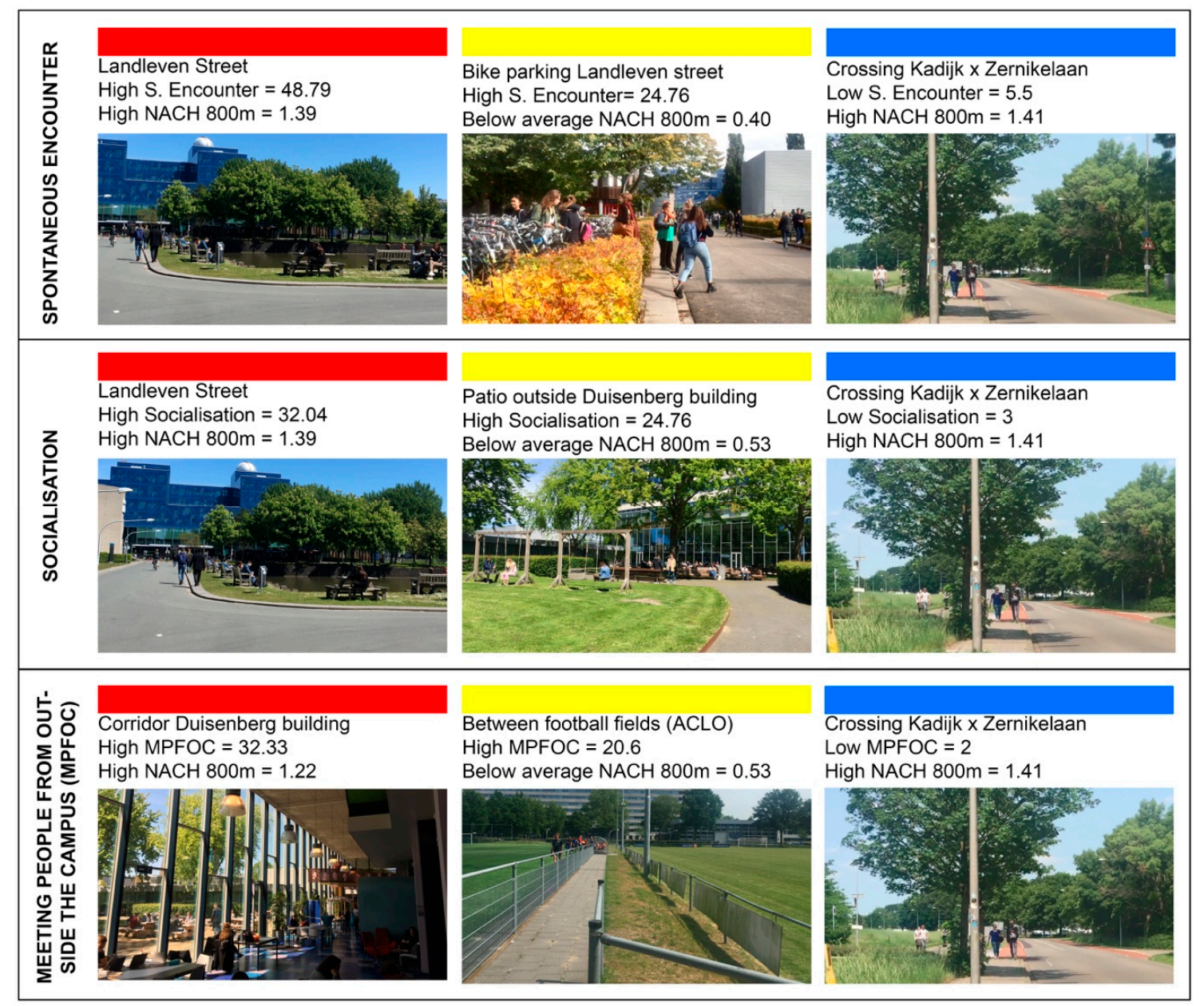

Figure 8. Observation spots illustrating the scatterplot analysis results.

In summary, the present results are significant in at least two major respects. One is in regards to the primary focus of this research, which was to empirically test the interface between spatial configuration and the perceptions of a sense of place through a mixed-methods approach. The findings of the yellow and blue categories suggest that a high potential for pedestrian movement and co-presence measured by NACH R800m does not determine whether or not people will engage with the built environment or creative encounters. Therefore, public places (or segments) indicated with high opportunities for spontaneous encounters, socialisation and MPFOC do not appear to depend entirely on their spatial configuration, but rather on the availability of activities, urban functions and physical features. In other words, a low potential for movement does not mean a low engagement between people and the built environment, as observed in the yellow category between the football fields. Furthermore, the high potential for movement determines the high engagement between people and the built environment, as seen in the blue category at the intersection of the Kadijk and Zernikelaan streets (see Figures 4 and 5). 
Additionally, this research provided insights into peoples' perceptions and behaviour in public spaces, within the context of satellite science precincts [85,86]. The results support evidence from previous observations, that buildings and public spaces of modernistic satellite science campuses are spatially and socially disconnected from the immediate environment $[7,72]$, resulting in a masterplan with a 'weak spatial structure' [15]. Commonly, in such a type of campus, public spaces are placeless environments, overshadowed by fragmentation and remoteness. These are consequences of a top-down modernistic masterplan, which was considered to be a 'creative solution' in post-war Europe. Therefore, we suggest that, for the Dutch context, Zernike campus is a representative study case, given that satellite science campuses are similar in terms of the way in which they were developed and implemented.

\section{Conclusions}

We empirically investigated the spatial aspects of creativity in public spaces at Zernike Campus, Groningen. Our findings contribute to Hillier's hypothesis that creativity is the fourth sustainability [11], and that contacts of the 'right kind' depend not only on the spatial configuration but also on people's perceptions of a sense of place, as suggested by Meusburger [5]. The results showed that people tend to see possibilities of creative encounters close to the places that they are familiar with, and in areas that are easy to reach in terms of accessibility. Public spaces with a high potential for movement and co-presence, as well as those that are perceived to have a high frequency of spontaneous encounters, socialization, and meeting people from outside the campus are the ones with the highest 'potential for creativity'. The outcomes of this research showed that creativity does not only depend on the accessibility of these public spaces or street segments, but also relies on the mix of active land use and activities, such as cafés, restaurants, green paths and urban seating. In contrast with the spatial configuration, the physical features and land-use mix appear to have a greater influence on creative encounters.

Based on Hilliers' and Meusburgers' theoretical frameworks, we used a mixed-methods approach to collect and analyse spatial and perceptual data, considering that 'creativity' both shapes and is shaped by university campuses and their public spaces. This method investigated the interface between the potential for pedestrian movement and co-presence throughout the campus, using space syntax and mapped perceptions of creative encounters by means of volunteered geographic information (VGI). These complementary methods proved to be useful in expanding our understanding of the ways in which the interface between the spatial configuration and user perceptions of creative encounters are fundamental empirical evidence to improve the masterplan design of satellite science parks and to transform public spaces into creative, dynamic and multi-purpose interconnected places [106]. This is in line with Wood and Dovey's [6] suggestion that the public space design of creative clusters, such as university campuses, depends on the combination of the land-use mix, activities and people. This is an effective 'creative solution' for the transfer and diffusion of tacit knowledge.

The limitations of this research relate to the space syntax analysis and the area of the data collection. Space syntax effectively measures the pedestrian movement and co-presence at central and 'organic' areas of the campus, such as the public spaces around Landleven Street and the Duisenberg building. However, in more peripheral areas, the same model tends to highlight the campus's loose maxi-grid of high speed and straight arterial roads. The other limitation is the data collection, where the VGI perceptual data represents 'patches' of human perceptions predominantly in the south of the campus. We therefore recognise that it does not fully represent the population of people working and studying there.

For future research, the following aspects should be addressed. First, perceptual data should be collected from an area incorporating the northern part of the campus, where companies are located. This will then make it possible to better understand creative encounters between people from the different organisations located on campus (e.g., the university of applied sciences and private companies). Second, a critical reflection on the mixed-methods approach for further application is needed. For example, the procedure of combining and categorising spatial configuration analysis with space syntax and VGI perceptual data should be reviewed. Both aspects play a fundamental role 
in understanding the use of public spaces and the richness of the community on campus; however, the datasets have a quite distinct logic. Therefore, we were not yet able to provide statistical associations between the two geospatial datasets. After revision and refinement, this mixed-methods approach can be used for external validation with other case-studies and comparative studies that explore differences and similarities between the spatial aspects of creativity of campuses, masterplan design and public space typologies, e.g., a comparison between Dutch inner-city campuses and science parks.

Author Contributions: Conceptualization, I.S., C.Y. and G.W.; methodology, I.S., C.Y., G.W.; formal analysis, I.S., C.Y., G.W.; data curation, I.S., C.Y., G.W.; writing — original draft preparation, I.S.; writing - review and editing, I.S., C.Y. and G.W.; supervision, C.Y. and G.W. All authors have read and agreed to the published version of the manuscript.

Funding: This research received no external funding.

Conflicts of Interest: The authors declare no conflict of interest.

\section{References}

1. Asheim, B.; Coenen, L.; Vang, J. Face-to-face, buzz, and knowledge Bases: Sociospatial implications for learning, innovation, and innovation policy. Environ. Plan. C Gov. Policy 2007, 25, 655-670. [CrossRef]

2. Storper, M.; Venables, A.J. Buzz: Face-to-face contact and the urban economy. J. Econ. Geogr. 2004, 4, 351-370. [CrossRef]

3. Van Winden, W.; Carvalho, L.; Miao, J.T.; Benneworth, P.; Phelps, N.A. Making 21th century knowledge complexes: Technopoles of the world revisited, 62-81. In Synergy Management at Knowledge Locations; Routledge: Abingdon, UK, 2015.

4. Strange, C.C.; Banning, J.H.; Delworth, U. Educating by Design: Creating Campus Learning Environments That Work; Jossey-Bass: San Francisco, CA, USA, 2001.

5. Meusburger, P.; Funke, J.; Wunder, E. Milieus of Creativity: An Interdisciplinary Approach to Spatiality of Creativity; Springer: Dordrecht, The Netherlands, 2009.

6. Wood, S.; Dovey, K. Creative multiplicities: Urban morphologies of creative clustering. J. Urban Des. 2015, 20, 52-74. [CrossRef]

7. Hajrasouliha, A.H. Master-planning the American campus: Goals, actions, and design strategies. Urban Des. Int. 2017, 22, 363-381. [CrossRef]

8. Kenney, D.R.; Dumont, R.; Kenney, G. Mission and Place: Strengthening Learning and Community through Campus Design; Praeger: Westport, CT, USA, 2005.

9. Strange, C.C.; Banning, J.H. Designing for Learning: Creating Campus Environments for Student Success, 2nd ed.; Wiley: San Francisco, CA, USA, 2015.

10. Meusburger, P. Knowledge environments in universities. Hung. Geogr. Bull. 2015, 64, 265-279. [CrossRef]

11. Hillier, B. The fourth sustainability, creativity: Statistical associations and credible mechanisms. In Complexity, Cognition, Urban Planning and Design; Springer: Cham, Switzerland, 2016; pp. 75-92. [CrossRef]

12. Benneworth, P.; Charles, D.; Madanipour, A. Building localized interactions between universities and cities through university spatial development. Eur. Plan. Stud. 2010, 18, 1611-1629. [CrossRef]

13. Da Silva, L.C.; Heitor, T.V.; Calvo-Sotelo, P.C. How exclusive do we want to be? Exploring the university realm in the contemporary urban territory. In Proceedings of the 11th International Space Syntax Symposium, SSS 2017, Lisbon, Portugal, 3-7 July 2017; Available online: http://www.11ssslisbon.pt/proceedings/ (accessed on 9 October 2020).

14. den Heijer, A.C.; Curvelo Magdaniel, F.T.J. Campus-City Relations: Past, Present, and Future. In Geographies of the University. Knowledge and Space; Springer: Cham, Switzerland, 2018; pp. 439-459. [CrossRef]

15. Hajrasouliha, A. Campus score: Measuring university campus qualities. Landsc. Urban Plan. 2017, 158, 166-176. [CrossRef]

16. Sailer, K. Creativity as social and spatial process. Facilities 2011, 29, 6-18. [CrossRef]

17. Appel-Meulenbroek, R. Knowledge Sharing through Co-Presence: Added value of facilities. Facilities 2010, 28, 189-205. [CrossRef]

18. Penn, A.; Desyllas, J.; Vaughan, L. The space of innovation: Interaction and communication in the work environment. Environ. Plan. B Plan. Des. 1999, 26, 193-218. [CrossRef] 
19. Brown, B.B.; Perkins, D.D. Disruptions in place attachment. In Place attachment; Springer: Boston, MA, USA, 1992; pp. 279-304.

20. Williams, D.; Patterson, M.E. Place, leisure and well-being. In Sense of Place, Health and Quality of Life; Eyles, J., Williams, A., Eds.; Ashgate Publishing Limited: Aldershot, UK, 2008; pp. 105-119.

21. Atkinson, S.; Fuller, S. Wellbeing and Place; Ashgate: Farnham, UK, 2012.

22. Sternberg, R.J.; Lubart, T.I. An investment theory of creativity and its development. Hum. Dev. 1991, 34, 1-31. [CrossRef]

23. Stokols, D.; Moos, R.H. The human context: Environmental determinants of behavior. Contemp. Sociol. 1979, 8, 155. [CrossRef]

24. Carmona, M. Contemporary public space, part two: Classification. J. Urban Des. 2010, 15, 157-173. [CrossRef]

25. Carmona, M. Re-theorising contemporary public space: A new narrative and a new normative. J. Urban. 2015, 8, 373-405. [CrossRef]

26. Hillier, B.; Hanson, J. The Social Logic of Space; Cambridge University Press: Cambridge, UK, 1989.

27. Hillier, B.; Penn, A.; Hanson, J.; Grajewski, T.; Xu, J. Natural movement: Or, configuration and attraction in urban pedestrian movement. Environ. Plan. B Plan. Des. 1993, 20, 29-66. [CrossRef]

28. van Nes, A.; Yamu, C. Introduction to Space Syntax in Urban Studies (in press); Springer: Dordrecht/Heidelberg/New York/London, UK, 2021; Available online: https://www.springer.com/gp/book/ 9783030591397 (accessed on 9 October 2020).

29. Yamu, C. It is simply complex(ity). Plan. Rev. 2014, 50, 43-53. [CrossRef]

30. Aleksandrowicz, O.; Yamu, C.; van Nes, A. Spatio-syntactical analysis and historical spatial potentials: The case of Jaffa-Tel Aviv. J. Interdiscip. Hist. 2018, 49, 445-472. [CrossRef]

31. Karimi, K. Space syntax: Consolidation and transformation of an urban research field. J. Urban Design 2018, 23, 1-4. [CrossRef]

32. Greene, M.; Penn, A. Socio-spatial analysis of four university campuses. The implications of spatial configuration on creation and transmission of knowledge. In Proceedings of the First Symposium of Space Syntax, London, UK, 1997; pp. 13.1-13.15.

33. Yaylali-Yildiz, B.; Czerkauer-Yamu, C.; Çil, E. Exploring the effects of spatial and social segregation in university campuses, IZTECH as a case study. Urban Des. Int. 2014, 19, 125-143. [CrossRef]

34. Adhya, A. Evaluating the campus-downtown relationship. In Proceedings of the Space Syntax 7 th International Symposium, Stockholm, Sweden, 8-11 June 2009; Koch, D., Marcus, L., Steen, J., Eds.; KTH: Stockholm, Sweden, 2009; pp. 1-19. Available online: http://citeseerx.ist.psu.edu/viewdoc/download?doi=10. 1.1.600.6546\&rep $=$ rep $1 \&$ type $=$ pdf (accessed on 13 October 2020).

35. Wu, X.; Law, S.; Heath, T.; Borsi, K. Spatial configuration shapes student social and informal learning activities in educational complexes. In Proceedings of the 11th International Space Syntax Symposium, SSS 2017, Lisbon, Portugal, 3-7 July 2017; Lisbon Instituto Superior Técnico: Lisabon, Portugal, 2017; pp. 33.1-33.9. Available online: http://www.11ssslisbon.pt/proceedings/ (accessed on 9 October 2020).

36. Poplin, A.; Yamu, C.; Rico-Gutierrez, L. Place-making: An approach to the rationale behind the location choice of power places. Iowa State University Campus as case study. ISPRS Archives 2017, 42, 73-81. [CrossRef]

37. Yaylali-Yildiz, B.; Spierings, B.; Çil, E. The spatial configuration and publicness of the university campus: Interaction, discovery, and display on De Uithof in Utrecht. Urban Des. Int. 2020. [CrossRef]

38. Cannas da Silva, L.; Heitor, T.V. Campuses as Sustainable Urban Engines. A Morphological Approach to Campus Social Sustainability; World Sustainability Series; Springer: Cham, Switzerland, 2017; pp. 259-276. [CrossRef]

39. Hillier, B.; University of Cambridge. Space Is the Machine: A Configurational Theory Architecture, 1st ed.; Cambridge University Press: Cambridge, UK, 1996.

40. Seamon, D. Life Takes Place: Phenomenology, Lifeworlds and Place Making; Routledge: New York, NY, USA, 2018.

41. Legeby, A. Patterns of co-Presence: Spatial Configuration and Social Segregation. Ph.D. Thesis, KTH Royal Institute of Technology, Stockolm, Sweeden, 2013. Available online: https://www.diva-portal.org/smash/ record.jsf?pid=diva2\%3A662753\&dswid=9258 (accessed on 13 October 2020).

42. Freeman, L.C. A set of measures of centrality based on betweenness. Sociometry 1977, 40, 35. [CrossRef] 
43. Moreira, A.S.; Serdoura, F. Modernist dwellings in Lisbon, Portugal: A syntactic approach to living use analysis. In Proceedings of the 11th International Space Syntax Symposium, SSS 2017, Lisbon, Portugal, 3-7 July 2017; Lisbon Instituto Superior Técnico: Lisabon, Portugal, 2017; pp. 17.1-17.18. Available online: http://www.11ssslisbon.pt/proceedings/ (accessed on 9 October 2020).

44. Seamon, D. Understanding place holistically: Cities, synergistic relationality, and space syntax. J. Sp. Syntax 2015, 6, 8-11.

45. Netto, V.M. “What Is Space Syntax Not?" Reflections on space syntax as sociospatial theory. Urban Des. Int. 2016, 21, 25-40. [CrossRef]

46. Pafka, E.; Dovey, K.; Aschwanden, G.D.P.A. Limits of space syntax for urban design: Axiality, scale and sinuosity. Environ. Plan. B Urban Anal. City Sci. 2020, 47, 508-522. [CrossRef]

47. Bell, S. Challenges for research in landscape and health. In Innovative Approaches to Researching Landscape and Health: Open Space: People Space 2; Routledge: Abingdon, UK, 2010; pp. 1-287.

48. Heft, H. Affordances and the perception of landscape. In Innovative Approaches to Researching Landscape and Health, Oxon; Routledge: Abingdon, UK, 2010; pp. 9-32.

49. Goodchild, M.F. Citizens as sensors: The world of volunteered geography. GeoJournal 2007, 69, $211-221$. [CrossRef]

50. Goodchild, M.F.; Li, L. Assuring the quality of volunteered geographic information. Spat. Stat. 2012, 1, 110-120. [CrossRef]

51. Kahila, M.; Kyttä, M. SoftGIS as a bridge-builder in collaborative urban planning. In Planning Support Systems Best Practice and New Methods; Springer: Dordrecht, The Netherlands, 2009; pp. 389-411.

52. Rantanen, H.; Kahila, M. The SoftGIS approach to local knowledge. J. Environ. Manag. 2009, 90, 1981-1990. [CrossRef]

53. Samuelsson, K.; Giusti, M.; Peterson, G.D.; Legeby, A.; Brandt, S.A.; Barthel, S. Impact of environment on people's everyday experiences in Stockholm. Landsc. Urban Plan. 2018, 171, 7-17. [CrossRef]

54. Laatikainen, T.E.; Haybatollahi, M.; Kyttä, M. Environmental, individual and personal goal influences on older adults' walking in the Helsinki Metropolitan Area. Int. J. Environ. Res. Public Health 2019, $16,58$. [CrossRef]

55. Rall, E.; Hansen, R.; Pauleit, S. The added value of public participation GIS (PPGIS)for urban green infrastructure planning. Urban For. Urban Green. 2019, 40, 264-274. [CrossRef]

56. Elwood, S.; Goodchild, M.F.; Sui, D.Z. Researching volunteered geographic information: Spatial data, geographic research, and new social practice. Ann. Assoc. Am. Geogr. 2012, 102, 571-590. [CrossRef]

57. Tang, Z.; Liu, T. Evaluating internet-based public participation GIS (PPGIS) and volunteered geographic information (VGI) in environmental planning and management. J. Environ. Plan. Manag. 2016, 59, 1073-1090. [CrossRef]

58. Lowery, D.R.; Morse, W.C. A qualitative method for collecting spatial data on important places for recreation, livelihoods, and ecological meanings: Integrating focus groups with public participation geographic information systems. Soc. Nat. Resour. 2013, 26, 1422-1437. [CrossRef]

59. Marcus, L.; Giusti, M.; Barthel, S. Cognitive affordances in sustainable urbanism: Contributions of space syntax and spatial cognition. J. Urban Des. 2016, 21, 439-452. [CrossRef]

60. Michelson, W.M. Behavioral Research Methods in Environmental Design; Dowden, Hutchinson \& Ross: Stroundsburg, PA, USA, 1975.

61. Mehta, V. Look closely and you will see, listen carefully and you will hear: Urban design and social interaction on streets. J. Urban Des. 2009, 14, 29-64. [CrossRef]

62. Heath, C. Analysing face-to-face interaction: Video, the visual and material. In Qualitative Research: Theory, Method and Practice; Sage: Thousand Ouks, CA, USA, 2004; pp. 266-282.

63. Clark, A.; Holland, C.; Katz, J.; Peace, S. Learning to see: Lessons from a participatory observation research project in public spaces. Int. J. Soc. Res. Methodol. 2009, 12, 345-360. [CrossRef]

64. Whyte, W.H. The Social Life of Small Urban Spaces; The Conservation Foundation: Washington, DC, USA, 1980.

65. Gehl, J. Life between Buildings: Using Public Space, 6th ed.; Danish Architectural Press: Copenhagen, Denmark, 2006.

66. Gehl, J.; Svarre, B. How to Study Public Life; Island Press: Washington, DC, USA, 2013.

67. Ewing, R.; Handy, S. Measuring the unmeasurable: Urban design qualities related to walkability. J. Urban Des. 2009, 14, 65-84. [CrossRef] 
68. Dober, R.P. Campus Design; John Wiley: New York, NY, USA, 1992.

69. Mehta, V. Streets and social life in cities: A taxonomy of sociability. Urban Des. Int. 2019, 24, 16-37. [CrossRef]

70. Göçer, Ö.; Göçer, K.; Başol, A.M.; Kıraç, M.F.; Özbil, A.; Bakovic, M.; Siddiqui, F.P.; Özcan, B. Introduction of a spatio-temporal mapping based POE method for outdoor spaces: Suburban university campus as a case study. Build. Environ. 2018, 145, 125-139. [CrossRef]

71. Boden, M.A. The Creative Mind: Myths and Mechanisms; Routledge: London, UK, 2004. [CrossRef]

72. Simonton, D.K. Creativity: Cognitive, personal, developmental, and social aspects. Am. Psychol. 2000, 55, 151-158. [CrossRef]

73. Funke, J. Psychologie der Kreativität (Psychology of creativity). In Psychologie Der Kreativität; Holm-Hadulla, R.M., Ed.; Springer: Berlin/Heidelberg, Germany, 2000; pp. 283-300.

74. Shalley, C.E.; Gilson, L.L.; Blum, T.C. Matching creativity requirements and the work environment: Effects on satisfaction and intentions to leave. Acad. Manag. J. 2000, 43, 215-223.

75. Glaeser, E.L.; Maré, D.C. Cities and skills. J. Labor Econ. 2001, 19, 316-342. [CrossRef]

76. Glaeser, E.L. Review of Richard Florida's the rise of the creative class. Reg. Sci. Urban Econ. 2005, 35, 593-596. [CrossRef]

77. Meusburger, P. Knowledge Environments at Universities: Some Theoretical and Methodological Considerations; Geographies of the University; Springer: Cham, Switzerland, 2018; pp. 253-290.

78. Rantisi, N.M.; Leslie, D.; Christopherson, S. Placing the creative economy: Scale, politics, and the material. Environ. Plan. A 2006, 38, 1789-1797. [CrossRef]

79. Raymond, C.M.; Gottwald, S.; Kuoppa, J.; Kyttä, M. Integrating multiple elements of environmental justice into urban blue space planning using public participation geographic information systems. Landsc. Urban Plan. 2016, 153, 198-208. [CrossRef]

80. CBS (Centraal Bureau voor de Statistiek). Bevolkingsontwikkeling; Regio per Maand. CBS Statline. Available online: https://opendata.cbs.nl/statline/\#/CBS/nl/dataset/37230ned/table?ts=1600098117888 (accessed on 14 September 2020).

81. Campus Groningen. Kennisinstellingen. 2019. Available online: https://campus.groningen.nl/access-totalent/kennisinstellingen-4 (accessed on 2 July 2019).

82. Magdaniel, F.C. Technology Campuses and Cities: A Study on the Relation between Innovation and the Built Environment at the Urban Area Level. PhD Thesis, Delft University of Technology, Delft, The Netherlands, 2016; pp. 1-476. [CrossRef]

83. Ng, W.K.B.; Appel-Meulenbroek, R.; Cloodt, M.; Arentze, T. Towards a segmentation of science parks: A typology study on science parks in Europe. Res. Policy 2019, 48, 719-732. [CrossRef]

84. UG (University of Groningen). The History of the University of Groningen. Available online: https://www.rug.nl/university-museum/history/university-of-groningen/1876-present (accessed on 2 July 2019).

85. Hoeger, K.; Christiaanse, K.; Bindels, E. Campus and the City: Urban. Design for the Knowledge Society; Gta: Zürich, Switzerland, 2007.

86. Buck Consultants. Inventarisatie en Meerwaarde van Campussen in Nederland. Inventory and Added Value of Campuses in The Netherlands. 2018. Available online: https:/campus.groningen.nl/contact/downloads (accessed on 15 October 2020).

87. Varoudis, T. DepthmapX Multi-Platform Spatial Network Analysis Software. Version 0.35. Developed by University College of London (UCL). OpenSource. Available online: https:/github.com/SpaceGroupUCL/ depthmapX. (accessed on 2 July 2019).

88. Hillier, B. Studying cities to learn about minds: Some possible implications of space syntax for spatial cognition. Environ. Plan. B Plan. Des. 2012, 39, 12-32. [CrossRef]

89. Hillier, B.; Iida, S. Network and psychological effects in urban movement. Lect. Notes Comput. Sci. 2005, 3693 LNCS, 475-490.

90. Al-Sayed, K.; Turner, A.; Hanna, S. Generative structures in cities. In Proceedings of the 8th International Space Syntax Symposium, Santiago, Chile, 3-6 January 2012; UCL: London, UK, 2012; pp. 1-18. Available online: https://www.ucl.ac.uk/bartlett/architecture/research/space-syntax-laboratory/2012-publications (accessed on 9 October 2020).

91. Sharmin, S.; Kamruzzaman, M. Meta-analysis of the relationships between space syntax measures and pedestrian movement. Transp. Rev. 2018, 38, 524-550. [CrossRef] 
92. Hillier, B. Spatial sustainability in cities organic patterns and sustainable forms. In Symposium A Quarterly Journal in Modern Foreign Literatures; Royal Institution of Technology: Stockholm, Sweden, 2009; pp. 1-20.

93. Hillier, B.; Vaughan, L. The city as one thing. Prog. Plan. 2007, 67, 205-230. [CrossRef]

94. Van Nes, A.; Yamu, C. Space syntax: A method to measure urban space related to social, economic and cognitive factors. In The Virtual and the Real in Planning and UrbanDesign: Perspectives, Practices and Applications; Routledge: London, UK, 2018; pp. 136-150.

95. Rashid, M. Space syntax: A network-based configurational approach to studying urban morphology. In Modeling and Simulation in Science, Engineering and Technology; Springer: Cham, Switzerland, 2019; pp. 199-251.

96. Kahila, M.; Broberg, A. Making cities wiser-Crowdsourcing for better decisions. In Proceedings of the International Federation of Surveyors working week, Helsinki, Finland, 29 May-2 June 2017.

97. Jöns, H.; Heffernan, M.; Meusburger, P. Mobilities of Knowledge: An Introduction; Springer: Cham, Switzerland, 2017; pp. 1-19.

98. Gumprecht, B. The American College Town; University of Massachusetts Press: Amherst, MA, USA, 2008.

99. NWO (Netherlands Organisation for Scientific Research). De nederlandse Gedragscode wetenschappelijke integriteit 2018. Justitiële Verkenn. 2018. [CrossRef]

100. GDPR (General Data Protection Regulation). European Union. 2019. Available online: https://eur-lex.europa. eu/legal-content/EN/TXT/?uri=CELEX:32016R0679 (accessed on 7 July 2020).

101. Adler, P.A.; Adler, P. Observational techniques. In Handbook of Qualitative Research; Denzin, N.K., Lincoln, Y.S., Eds.; Sage Publications: Thousand Oaks, CA, USA, 1994; pp. 377-392.

102. Costa, P.; Lopes, R. Urban design, public space and the dynamics of creative milieux: A photographic approach to Bairro Alto (Lisbon), Gràcia (Barcelona) and Vila Madalena (São Paulo). J. Urban. Des. 2015, 20, 28-51. [CrossRef]

103. Bereitschaft, B. Equity in microscale urban design and walkability: A photographic survey of six Pittsburgh streetscapes. Sustainability 2017, 9, 1233. [CrossRef]

104. Boutellier, R.; Ullman, F.; Schreiber, J.; Naef, R. Impact of office layout on communication in a science-driven business. $R$ D Manag. 2008, 38, 372-391. [CrossRef]

105. Holland, C. Joseph Rowntree Foundation. In Social Interactions in Urban. Public Places; Public Spaces Series; Joseph Rowntree Foundation: York, UK, 2007.

106. Castells, M. Space of flows, space of places: Materials for a theory of urbanism in the information age. In The City Reader, 5th ed.; Routledge Urban Reader Series; Routledge: London, UK, 2001; pp. 572-582.

Publisher's Note: MDPI stays neutral with regard to jurisdictional claims in published maps and institutional affiliations.

(C) 2020 by the authors. Licensee MDPI, Basel, Switzerland. This article is an open access article distributed under the terms and conditions of the Creative Commons Attribution (CC BY) license (http://creativecommons.org/licenses/by/4.0/). 